\title{
From the Trial to the Transcription: Listening Problems Related to Thematic Knowledge. Some Implications for the Didactics of Court Interpreting Studies
}

\author{
Carmen Bestué
}

\begin{abstract}
Interpreting is a phenomenon of such complexity that, particularly in highly specialized fields, such as court interpreting, it is easy to detect errors and omissions made not only by students, but even by experienced professional interpreters. These errors are often attributed to a lack of competence on the part of the interpreter, but they can also arise from the highly specialized nature of the setting in which the task is performed. The present study focuses on the second of these two factors in relation to both transcription and interpretation. It sets out to characterize errors of comprehension that may precede target discourse production in another language due to a particular setting in which much of the dialogic exchange takes place within a closed circuit, in the form of a triangle consisting of the judge, the defence counsel and the prosecution, and from which the defendant (and his or her interpreter) is excluded. To this end, we worked with an oral corpus of recordings of real criminal trial proceedings and the transcripts of those proceedings made by technicians employed and trained by the project Translation and Interpreting in Criminal Proceedings (TIPp), led by Universitat Autònoma de Barcelona.
\end{abstract}

Keywords Court translation and interpreting, transcription of oral corpora, spoken language comprehension, courtroom language, specialized languages, working with interpreters

If comprehension is faulty, the process of interpreting will be faulty as well. (Trabing 2002: 11)

\section{Introduction}

According to Padilla (as quoted in Bajo et al. 2000: 128) it is estimated that $80 \%$ of the effort and cognitive resources involved in interpreting is devoted to listening to and understanding the speech, while the remaining $20 \%$ is focused on producing the message in the other language. This listening effort is even greater when interpreting in a highly specialized context such as a court of law. The oral trial in criminal proceedings is characterized by a discourse in which the density of information is high, combining general legal terminology with the features peculiar to oral legal discourse and a wide variety of cultural backgrounds represented by the actors involved (cf. Griffin/Cole 2007). It should also be noted that the dialogic communication serves a very specific pragmatic purpose (cf. Dueñas et al. 2012: 769). In our view, the

\section{Zitiervorschlag / Citation:}

Bestué, Carmen (2019): "From the Trial to the Transcription: Listening Problems Related to Thematic Knowledge. Some Implications for the Didactics of Court Interpreting Studies." Fachsprache. Journal of Professional and Scientific Communication 41.3-4: 159-181. 
difficulty of comprehension, in the Spanish context, is aggravated by the marked tendency on the part of members of the judiciary (judges, prosecutors and attorneys), to rely excessively on reading prepared material out loud as opposed to speaking spontaneously.

The difficulty of understanding legal language has been discussed at length (in this context, see the recent work by Lambertini 2016: 82-89) with regard to the possible negative impact both on the defence and the reaction of the receiver of the message. However, almost all of the works reviewed have adopted an experimental methodology, with no or very limited focus on the recognition of the oral linguistic sign in terms of the listener's knowledge and expectations. This article presents the analysis of certain types of listening errors measured in the transcription work of authentic recordings of oral criminal trials. In looking at the problems that transcribers encountered and the analysis of the errors we consider that these results may be relevant for assessing the listening problems experienced by legal interpreters. Our aim is to use this transcription material as 'secondary data' in the hope that it may be of some help to formulate hypotheses that could be tested experimentally in interpreting studies. Given that transcription depends on the perception of speech (Fraser 2003: 204), an analysis of transcripts and the problems of recognition of speech on the part of the transcribers gives an idea of the complexity of legal discourse and the listening effort required of a court interpreter. In revising and correcting the transcription errors detected in the text transcribed, we have discovered an interesting area of study which provides data on the listening effort without the need to interview or assess the participant to verify his or her level of comprehension. Our purpose in this article is to analyze the correlation between recognition of the linguistic sign and the thematic and expert knowledge of the transcriber and, as an indirect method, to reflect on the linguistic and extralinguistic anticipation skills that court interpreters need to acquire.

Aware of the unconventional nature of this approach, we have carried out a thorough review of the existing literature from a range of different disciplines. In the field of interpreting studies, numerous studies have focused on the challenges posed by the judicial context to the task performed by the interpreter (cf. e.g. Berk-Seligson 1990/2002, Colin/Morris 1996, Pym 1999, Angelelli 2004, Hale 2004, 2007, Mikelson 2010, Martin/Ortega 2013). However, the listening effort, in the sense of the ability to identify oral linguistic signs, is an area that has received little attention in the field of court interpreting. The transcription of court proceedings as evidence in the context of police and judicially authorized phone tapping has been analyzed exhaustively, "emphasizing that transcription is always partial" (Bucholtz 2009: 1463), as well as in cases of controversial transcriptions of statements by witnesses speaking in a language different from that of the court (cf. Fraser 2003, Fishman 2006, Bucholtz 2009, Rainof 2011). Transcription errors have been studied mainly from a linguistic perspective, with a view to enhancing knowledge of oral language and identifying how it is spoken in different communities (Pallaud 2002, Chiari 2007). Moreover, the analysis of oral discourse in trial proceedings has, with very few exceptions, been carried out from a participatory research perspective in which the researcher, as a spectator of the interaction, makes his or her own recordings (Angermeyer 2009, Hunt-Gómez 2015). However, in real-life interpretations, the transcript is an indispensable tool yielding an "analyzable" format (Niemants 2012), and a number of research groups have been working for several years on the reconstruction of the mental processes of interpreters by analyzing transcriptions (e.g. Meyer 1998).

It is generally accepted that thematic knowledge, in the sense of a high level of specialization, is an essential requirement for a professional level of interpretation; some authors even claim that accreditation as an interpreter is not, in itself, sufficient to qualify an interpreter 
to work in a legal context (Roberts-Smith 2009: 32). Training and specialization are therefore essential to ensure a high-quality interpretation, which in turn contributes to enhance working conditions and professional recognition for interpreters in the legal context. To this end, one of the objectives of the TIPp ${ }^{1}$ research project, in the context of which our own research has been carried out, was to obtain official recordings of criminal trial proceedings directly from the law courts in order to transcribe their contents and use the resulting materials to prepare didactic resources with a view to improving the training of court interpreters. The results presented in this article correspond to the listening and transcription phase of oral recordings, the transcription process, and the analysis of errors of comprehension detected in the first nine trials selected for the pilot study in the research. Difficulties in identifying certain formulations, which are subsequently solved in the revision phase, permit us to analyze the importance of expert knowledge and to detect whether there is a correlation between the type of dialogic situation and the frequency of transcription errors. We present the findings of this revision phase and we endeavour to use them as the basis to formulate some hypotheses related to the degree of thematic knowledge needed in the context of criminal trials for comprehension purposes in court interpreting.

\section{The comprehension of oral language in criminal proceedings}

Although legal language has been amply described by numerous authors from the perspective of translation (cf., for example, Alcaraz Varó/Hughes 2002, Mayoral 2003, Bestue 2013, 2016, Prieto-Ramos 2015, Sánchez-Ramos/Vigier-Moreno 2016), as yet few authors have dealt with the language used in trials (Calvo 2002, Soriano 2004, Ruiz 2013) and still fewer have studied the specific field of language as it is used in criminal trials (Peñaranda 2011, Onos 2014, Orts/ Almela 2014, Borja/García-Izquierdo 2016). While court interpreting has recently aroused more interest (cf. Berk-Seligson 1990/2002, Wadensjö 1998, Angelelli 2004, Hale 2004, Angermeyer 2009, Ortega 2015, and particularly the work by Dueñas/Vásquez/Mikkelson 2012), there is still a lack of detailed descriptions of the oral language used in criminal proceedings in Spain for interpreting purposes (from a linguistic perspective it is important to mention the work of Montolío 2012 and Torres Alvarez 2016), and, consequently, a paucity of relevant teaching materials. Interpreters are therefore obliged to painstakingly compile their own terminology and phraseology glossaries by resorting to monolingual sources, legal handbooks, etc., in order to prepare their interventions. The scarcity of publicly available recordings of actual trials in Spain, compared with the widespread availability of recordings of English-language trials under various jurisdictions, does not contribute to improve training, which in the best-case scenarios relies on role plays and simulated situations, as well as observing trials from the public gallery.

Interpreters who work in highly specialized contexts usually perceive themselves as subordinate to the experts, as professionals "physically surrounded by 'real' experts" (Gile 2009a:

\footnotetext{
TIPp (Translation and Interpreting in Criminal Proceedings) is the abbreviation of the research project La calidad de la traducción como factor de garantía del proceso penal: desarrollo de recursos al servicio de los intérpretes judiciales de rumano, árabe, chino, francés e inglés, funded by the Ministerio de Economía y Competitividad (FFI2014-55029-R), led by Universitat Autònoma de Barcelona, in which researchers from another three Spanish universities have taken part. For further information, see $<\mathrm{http}: / /$ pagines.uab.cat/tipp/>.
} 
149), or even "outsiders to the field" (Gile 2009a: 38). Apart from possible psychological reasons, as well as the status of the profession itself, inappropriate use of terminology, in addition to the perception of the other agents involved in the communicative situation, are factors of undeniable importance when it comes to gauging the quality of court interpreting (Berk-Seligson 1990/2002, Angermeyer 2009). According to Gile:

When appropriate terminology is not found by the reader in a target-language text, this lowers the credibility of the translator and the translation and weakens its impact, hence a loss of communication effect from the author's or speaker's viewpoint. (Gile 2009a: 130)

\subsection{The context: oral discourse in Spanish law courts}

The oral language (cf. e.g. Dueñas/Vásquez/Mikkelson 2012) used in criminal trials is characterized by a high density of information in the original speech, given that the facts must be described precisely in order to determine whether or not a crime has been committed, and the procedural documents (which sometimes run to thousands of pages) need to be reproduced in their entirety in the comparatively brief space of time during which the oral trial takes place. An added difficulty stems from the fact that the participants come from a wide range of different cultural backgrounds, all of which are reflected in the oral communication: the highly specialized terminology of the judiciary, the slang used by offenders, the technical language found in the expert reports, dialectal speech in the witnesses' evidence, etc. Moreover, the dialogic communication in which attorneys and prosecutors engage during the examination of witnesses conforms to a definite syntactical structure designed to fulfil a concrete pragmatic purpose, such as extracting or confirming information, disconcerting witnesses, throwing them off their guard or even ridiculing them. In addition to all these characteristics, in the Spanish context we must also note a pronounced tendency on the part of the judiciary to rely heavily on the oral delivery of written speeches rather than spontaneous speech, thus erecting a further barrier to comprehension, since, as Soler Caamaño (2006: $142 \mathrm{f}$.) points out, orally delivered written discourse is more dense, contains fewer elements of oral spontaneity, and is usually distinguished by its unnatural intonation.

Legal oratory in Spain bears the clear imprint of its written origins. Similarly, oral language in Spanish courts conforms to a specific blueprint characterized by a legally predetermined structure and a written paradigm of discourse which influences the spoken word, thus making it difficult for those who have not had prior access to the written documents to follow and understand what is being said. Indeed, the participants in the oral trial make abundant references to the written documents included in the pre-trial proceedings, which, being known to the triangle formed by the attorney, the prosecutor and the judge, are not explicitly mentioned, but are merely referenced during the hearing. Thus, much of the oral discourse which takes place during a trial is in fact written discourse intended to be read out loud, whose primary purpose is to reinforce the arguments put forward by each of the parties rather than to address the attention of the defendant or the defendant's interpreter. Although it is not our intention in the present article to offer a description of the above-mentioned markers of written language found in legal oral language, by way of example we shall cite some expressions that are frequently repeated in criminal trials, such as por reproducidas ('so reproduced'), a definitivas ('become final'), a definitivas y formulamos alternativas igual que el resto de mis compañeras ('become final and we formulate alternative pleadings like our colleagues'), quedan los otorga- 
mientos realizados ('therefore, the offer of actions is made'), se interesaría la pena de ('we ask for a sentence of'), como se interesaba en nuestro escrito ('as requested in our pleadings'), etc.

In our opinion, this characteristic of legal oratory has an adverse impact on the expository clarity of the oral proceedings for non-experts and, at the very least, results in the omission of information that should be made available to the users of the justice system, regardless of the latter's procedural status. One of the most critical points in the trial proceedings, framed in a liturgy incomprehensible to any lay person, occurs when the parties - the public prosecutor and the defence - proceed in a ritualized fashion to change or, in legal language, "to elevate" the initial pleadings to final pleadings. During the hearing, it is common practice in Spain for both the prosecution and the defence attorneys to propose that the initial pleading be converted to a final pleading without elaborating on the content or their arguments, as the provisional pleadings quoted in the initial pleadings are already incorporated in the proceedings. If no modifications are proposed to the pleadings, the members of the judiciary merely say $i a$ definitivas? ('converted to final?'), and when a modification is proposed, they simply mention the specific paragraphs they wish to modify without providing any kind of relevant contextual information. Consequently, anybody who has not had access to the case records is totally excluded from the dialogic exchange and therefore cannot fully contextualize the interventions. The following three examples taken from the corpus transcribed by the TIPp project illustrate the types of interventions frequently found in oral trials of criminal proceedings:

(1) Fiscal: "A efectos de llegar a una conformidad con el acusado, modificamos nuestro escrito de conclusiones provisionales, de la conclusion primera para añadir que el acusado por causas no imputables al detenido ha tenido paralizada la causa eh, en varios periodos."

[Prosecution: "With a view to reaching a plea agreement with the defendant, we modify our provisional pleadings, adding to the first pleading that the defendant's case, for reasons not attributable to the detainee, has remained pending in stasis, er, for several periods of time."] ${ }^{2}$

(2) Abogado de la defensa: "A la vista de la modificación interesa se dicte sentencia de conformidad con la pena solicitada en la sustitución por pena de multa".

[Defence attorney: "In light of the modification, we ask that judgment be handed down in accordance with the sentence requested, replacing it with a fine."]

(3) Abogado de la defensa: "Eh, simplemente modificaríamos el extremo segundo del escrito de la defensa, en el sentido de añadir que no se aprecia comisión del delito de hurto pero se aprecia que se ha cometido una falta".

[Defence attorney: "Er, we would simply modify the second point of the defence plea, adding that it is our contention that no crime of theft has been committed, but that a petty theft has been committed."]

Advance preparation in writing of an oral intervention allows for greater precision in terms of structure as well as obvious expository advantages from the speakers' point of view. When delivering a speech or intervention written in advance, the speakers are able to be more precise in their exposition because the ideas have already been set out according to an established

$2 \quad$ All the texts are translated by the author of this article. 
pattern familiar to all the legal specialists, thus providing an appropriate format in which to frame the arguments. In so doing, however, they run the risk of excluding all those following the interaction who have not had access to the pre-established blueprint. Another factor which contributes to the difficulty of understanding the oral language used in court is the excessive speed of delivery, particularly on the part of judges and prosecutors, with its subsequent impact on intonation and vocalisation.

With few exceptions, orators have a pre-established written script which, precisely because it is known to all those taking part, that is to say, the closed circuit formed by the judge, the defence counsel and the prosecution, the latter neglect to make explicit and thus "communicate" all of the information to everybody present. This may be due to time constraints, the accumulation of cases scheduled for any given day and, we might add, the forensic culture of the legal profession. Admittedly, the risks posed by the opacity of legal language in translation have been described (Orts 2015), but the lack of expository clarity is a much more serious matter in oral trial proceedings, where it can lead to a breach of the defendant's right to information during criminal court proceedings.

It should be pointed out that interpreters do not usually have access to the pre-trial proceedings and will therefore have difficulty contextualising the information exchanged during the proceedings that they are required to reproduce in the target language for their interlocutor(s).

\subsection{Comprehension problems from the point of view of interpreting}

The various aspects of human speech comprehension have been thoroughly established by the academic community. These include the nature of the speech, as well as the role of the receiver of the message, including his or her own knowledge and expectations regarding the sender of the message. Thus, Fraser describes the act of listening as follows:

In fact, when we listen to someone speaking, what we hear depends on three things: a) the sounds that they utter; b) the context of other sounds in which the particular sounds to which we are attending are uttered; and c) the listener's knowledge and expectations about the language the speaker is using, and the situation in which they are speaking. (Fraser 2003: 204)

Studies on translation and interpreting have analyzed problems of comprehension from a variety of perspectives.

From a cognitive perspective on translation and interpreting tasks, Bajo et al. (2000) analyzed those processes of comprehension in which working memory plays a key role. In a later study, adopting an integrated approach to translating and interpreting tasks, they described the kind of knowledge necessary to activate and process discourse comprehension, including lexical, semantic, conceptual, syntactical and pragmatic knowledge (Padilla et al. 2005). However, they conclude that there is no evidence to show that translators use different processes, depending on the material translated. Dillinger (1994: 185) suggests that "comprehension in interpreting is characterized by all of the same component processes as listening [...] with an emphasis on semantic processing, in particular proposition generation". Indeed, this author argues that the interpreter must have the same knowledge as the person he or she is interpreting in order to ensure efficient communication. Enhanced comprehension relies on an 
efficient working memory such as that developed by experienced interpreters, but also on specialization, acquired thanks to their thematic knowledge. All the authors cited agree on the importance of the interpreter's familiarity with the context in the sense of speech community, either through familiarization with the code (Pfeiffer 1998), through sharing that code (Philipsen 1992: 130), or thanks to the interpreter's "preexisting language resources" (Hale 2004: 3). In short, the specialization of interpreters during their training or in the course of their professional career is essential both with regard to the reformulation of the speech in the target language and with a better comprehension of the linguistic sign.

Gile (2009b) defines the components of interpreting as "efforts", which he further subdivides into four functional actions: listening, speech production, short-term memory and coordination. At the very least, the listening effort involves recognition of the words uttered in the source language without there being a "one-to-one relation" between the sound heard and each of the phonemes, words or groups of words uttered by the speaker (Gile 2009a: 160). In Gile's view, the comprehension effort required to grasp the message in the original language begins with listening to the signal and continues until the meaning of the words and phrases is fully apprehended. However, listening to the signal and recognizing the words uttered does not occur in a vacuum, as there is always some sort of semantic representation of the content of the source speech, including a plausibility analysis and, probably, anticipation, which means that the interpreter who has to produce a speech in his or her target language tends to reconstruct the segment with reference to its context.

As Tolosa (2014) observed when analyzing the comprehension process in the training of translators from a psycholinguistic perspective, "it is impossible for a translator to translate a text without having a minimum understanding of it both in linguistic (terminological) and extralinguistic (pragmatic and thematic) terms" (Tolosa 2014: 1282). Tolosa writes: "the comprehension of a text is possible because the readers of the text have previously had similar or analogous experiences that they remember, organize and call upon to interact with the representation of the information" (Tolosa 2014: 1279).

Cognitive linguistics has studied the relative importance of inference in the comprehension of written discourse:

Nevertheless, we believe that Bruner's old notion of the mind as an "inference machine" is still valid; indeed, its validity is steadily gaining ground by attaching greater importance to the inferences construed on the basis of the subject's knowledge. So much so, in fact, that nowadays it is impossible to conceive of an adequate theory of text comprehension that fails to take into account the wealth of inferences generated when the reader constructs a mental model or a situation model concerning the content of the text in question. (León 2001: 124)

However, as Escudero Domínguez points out, comprehension harnesses different kinds of knowledge, both linguistic and non-linguistic, each providing an essential ingredient.

Both the reader of a text and the listener of a conversation also need to carry out the following processes: a) recognize the signal emitted by the speaker or the graphic elements of a text; b) break down the signal into its constituent parts; c) access the mental lexicon based on the product of the segmentation processes; d) select the appropriate word from the lexicon which contains more than 30,000 entries; e) construe the grammatical structure; $f$ ) identify the semantic relations between the words in the utterance; $g$ ) extract the 
train of thought from the various utterances which are being or have been processed; $h$ ) generate the context in which the information is processed; i) construct a coherent representation of what has been read or heard; $j$ ) contextualize the information obtained at a pragmatic and/or social level. (Escudero Domínguez 2010: 3)

In summary, the nature of the speech together with the listener's knowledge (both linguistic and extralinguistic) and his expectations have an impact on his comprehension skills. One could consider that the emphasis in comprehension should be on semantic processing (the specific terms of the field), but the structure of the language and the specific syntactical formulations are also essential ingredients of the kinds of knowledge that the listener has to possess in order to discern the specific sounds, as we will show in Section 3.

\subsection{Comprehension problems in the transcription of oral corpora}

Our assumption is that the factors relating to the difficulty of the subject matter that affect the listener's perception of a speech are the same as those which affect transcription. Our proposal is that the errors detected in transcription may be extrapolated to the interpreter's perception of speech during court proceedings.

Although the transcriber does not form part of the actual communicative situation, therefore missing the non-verbal dimension and the opportunity to request clarification from the participants, the benefits of being able to listen to any fragment posing a problem as many times as necessary, as well as having access to additional documentation resources, far outweigh the contraints imposed on the interpreter. For that reason, the extrapolation that we propose from the transcription work to the interpretation work regarding the listening phase is necessarily conservative.

On the face of it, the transcription of good quality oral recordings (as in the case of the majority of the recordings in our corpus) would appear to be a task within the capability of anyone who has received specific training, provided that they have enough patience.

However, our research on TIPp corpus shows the opposite: transcriptions by trained translators are not devoid of errors. These errors are not specifically concentrated on complex legal terms but on more common words forming part of legal expressions, with the consequence of significantly altering the meaning of the text. It therefore supports our claim that the transcriber's thematic knowledge, including mastery of its complex syntactical constructions, has a direct impact on his or her recognition of the sounds heard, and there is a clearly observable direct impact of the transcriber's knowledge on the result of the transcription. In this regard, Fraser stresses that although the errors detected in a transcription do not generally give rise to problems of sense or meaning, the latter are greater when the transcriber does not share the same thematic knowledge as those participating in the exchange:

If the transcriber does not share the same knowledge as the participants in the original conversation -for example in transcriptions of my own talks, the word 'phonological' has been transcribed as 'psychological'. (Fraser 2003: 218)

As in the case of comprehension, the transcription of a speech read out loud is more difficult than when the speech is spontaneous, as there is less expressiveness in the voice, and vocalization and pronunciation may be less careful. Speeches that are read out loud tend to be distinguished by a greater density of information, fewer features of spontaneous speech and less 
natural intonation (Soler Caamaño 2006: 142). It is therefore important to observe whether or not a greater number of transcription errors can be detected in the fragments read out loud by the participants than in the case of the more spontaneous interventions, such as, for example, those of the direct user of the interpretation, in other words, the person whose knowledge of the official languages is limited.

While it is true that in any listening situation, precise recognition of the units of sense is inseparable from a thorough thematic knowledge of the topic in hand, the difficulty is even greater in a judicial setting, where the dialogic situation rarely addresses the attention of non-expert participants (except in the examination phase and when the defendant is given the right of allocution). Hence, the communicative situation is a closed circuit formed by specialists, who only rarely address the deponent in order to obtain the information that they require.

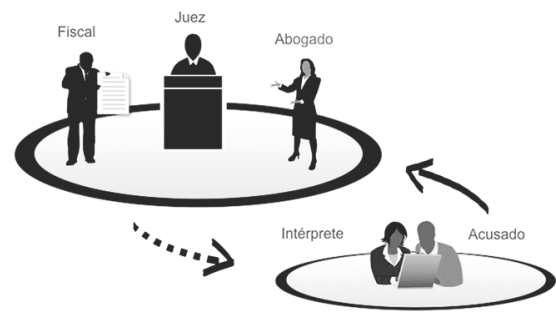

Figure 1: Characterisation of the dialogic situation in oral trial proceedings

Thus, for the purpose of this paper, we are interested in assessing whether recognition of the linguistic unit by transcribers is hampered in the communicative situation where participants are talking to their peers. In this case, complex syntax together with speed and less careful vocalization or pronunciation are probably factors which have an impact on the diminishing listening capacity of the receiver. We are also interested in categorising the errors that have an impact on meaning or sense.

\section{Object of study: \\ the transcription of the oral corpus of criminal proceedings}

Our main assumption regarding the importance of thematic knowledge in the listening phase is the result of observations carried out during a research project on interpreting in criminal proceedings, the TIPp project, that led us to set a controlled environment for the transcription of oral criminal proceedings. The following sections address the detailed methodology applied to the production of the research, our proposed classification of observed errors and the results.

\subsection{Methodology}

This section describes the steps followed in selecting the corpus of oral criminal proceedings and the production of the transcriptions.

In October 2015, within the framework of the TIPp research project, we began the process of transcribing the oral corpus of criminal proceedings previously compiled using the Exmar- 
alda programme, a unique tool which simultaneously permits both the transcription of an oral corpus and its semantic analysis (for a more detailed description of the project, the type of transcription used and the labeling of the corpus, cf. Orozco-Jutorán 2018. To this end, a team was formed consisting of a core of four transcribers (all of whom had received previous training in translation or linguistics, including one postdoctoral researcher and three $\mathrm{PhD}$ students). Other transcriptions were carried out with the participation of student volunteers but were discarded from this corpus rather rapidly. Before embarking on the transcription, the transcribers received specific training in the form of seminars totalling 20 hours, which included: familiarization with the transcription computer program; research methodology; interpreting techniques and strategies, and conceptual and terminological training relevant to the type of criminal trial proceeding selected for the creation of the oral corpus.

The seminar addressing thematic knowledge had a special focus on the Spanish abbreviated criminal proceeding, its phases and caracteristics, and was centered on the specific terminology and the more common formulaic expressions encountered in real settings. Such expressions are rarely found in procedural law handbooks and legal dictionaries, which are the reference works most commonly consulted by professional interpreters. Still less are they to be found in bilingual dictionaries. Therefore, in the training of our transcribers we worked with a didactic approach based on the recreation of situations of real trials but also in the translation of those elements of oral language that do not have specific entries in the existing terminological and phraseological databases, as the examples in Table 1 show. In the context of a trial, the explicitation examples shown above are the only ones recommended, whereas in a different setting, such as an attorney-client interview, the communicative translation also proposed could be acceptable. Together with the examples presented in Table 1, other recurrent utterances, that we call formulaic legal oral expressions, were introduced in the training sessions previous to the transcription work, as we anticipated that a lack of their semantic representation could interfere in the listening process.

Table 1: Proposed translations of formulaic legal oral expressions used in trial proceedings

\begin{tabular}{|l|l|l|}
\hline Por reproducidas & $\begin{array}{l}\text { We ask for the reproduction } \\
\text { of the written documentary } \\
\text { evidence proposed for the trial } \\
\text { without reading it aloud }\end{array}$ & $\begin{array}{l}\text { - So reproduced } \\
\text { - So reproduced without the } \\
\text { reading }\end{array}$ \\
\hline A definitivas & $\begin{array}{l}\text { There are no changes in the } \\
\text { provisional pleadings proposed } \\
\text { before the trial }\end{array}$ & $\begin{array}{l}\text { - We ratify the initial/provisional } \\
\text { pleadings } \\
\text { The initial/provisional plea- } \\
\text { dings become final }\end{array}$ \\
\hline
\end{tabular}

After the training period, the transcribers began working directly with the Exmaralda program $^{3}$. The transcription process was carried out in three stages: a first stage of transcription proper conducted by a transcriber, a revision stage carried out by another member of the group, and a final revision and correction carried out by a legal specialist (the author of the present article). All revisions were conducted by checking the transcription against the oral recording, thus ensuring an authentic, error-free corpus.

3 For more information about Exmaralda program see https://exmaralda.org/en/about-exmaralda/. 
The transcription was carried out in the relatively stress-free environment afforded by a research room at the university, using good quality earphones and with the means of pausing and skipping forward and backward in the recording as often as necessary. Nevertheless, as some authors have pointed out, "transcribing is an extremely painstaking process, requiring a time expenditure many times the duration of the speech itself" (Fraser 2003: 217), in this case transcribers invested, on average, more than fifty minutes of transcription per minute listened.

The results presented in this article include the errors detected and corrected by myself when the transcription did not adhere to the original sound, conducted during the third revision phase of the trials selected for the project's pilot study. Even if we cannot escape our own subjectivity, since the purpose of the transcriptions were not to conduct discourse analysis but to create materials to describe interpreting decisions in real trials, I considered myself qualified to perform this task. To be precise, the corpus consists of nine complete transcriptions of nine trials (three for each language combination, including English, French and Romanian). The corpus of transcriptions analyzed in this study consists of a total of 26,990 words transcribed by trained, expert transcribers.

Anecdotal mistakes such as typographical errors were excluded as not relevant for the purposes of the present study. In order to ensure greater uniformity in the sample, all the trial proceedings transcribed belong to the same type of proceeding, known as "Procedimiento Abreviado" (P.A.) (Abbreviated Criminal Proceedings), and were selected exclusively from those corresponding to the Criminal Courts of Barcelona. The total number of errors detected represents $0.54 \%$ of the total number of words transcribed, which allows us to conclude that the average error rate in our corpus is one error every 185 words. As shown in Table 2, the three transcribers show similar error percentages with small variations between $0.51 \%$ and $0.63 \%$.

Table 2: Description of the errors detected in the corpus of transcriptions analysed

\begin{tabular}{|l|c|c|c|}
\hline Type of text & Number of words & Number of errors & Percentage \\
\hline 3 P.A. English-Spanish & 13,877 & 71 & $0.51 \%$ \\
\hline 3 P.A. French-Spanish & 4,917 & 31 & $0.63 \%$ \\
\hline 3 P.A. Romanian-Spanish & 8,196 & 44 & $0.54 \%$ \\
\hline TOTAL & 26,990 & 146 & $0.54 \%$ \\
\hline
\end{tabular}

However, when looking at error percentages text by text done by the same transcriber, percentages fluctuate more (cf. Figure 2), indicating a clear impact of the human factor or differences in the characteristics of the oral texts. In the nine analyzed transcriptions, this percentage varies between $0.25 \%$ and $1 \%$. 


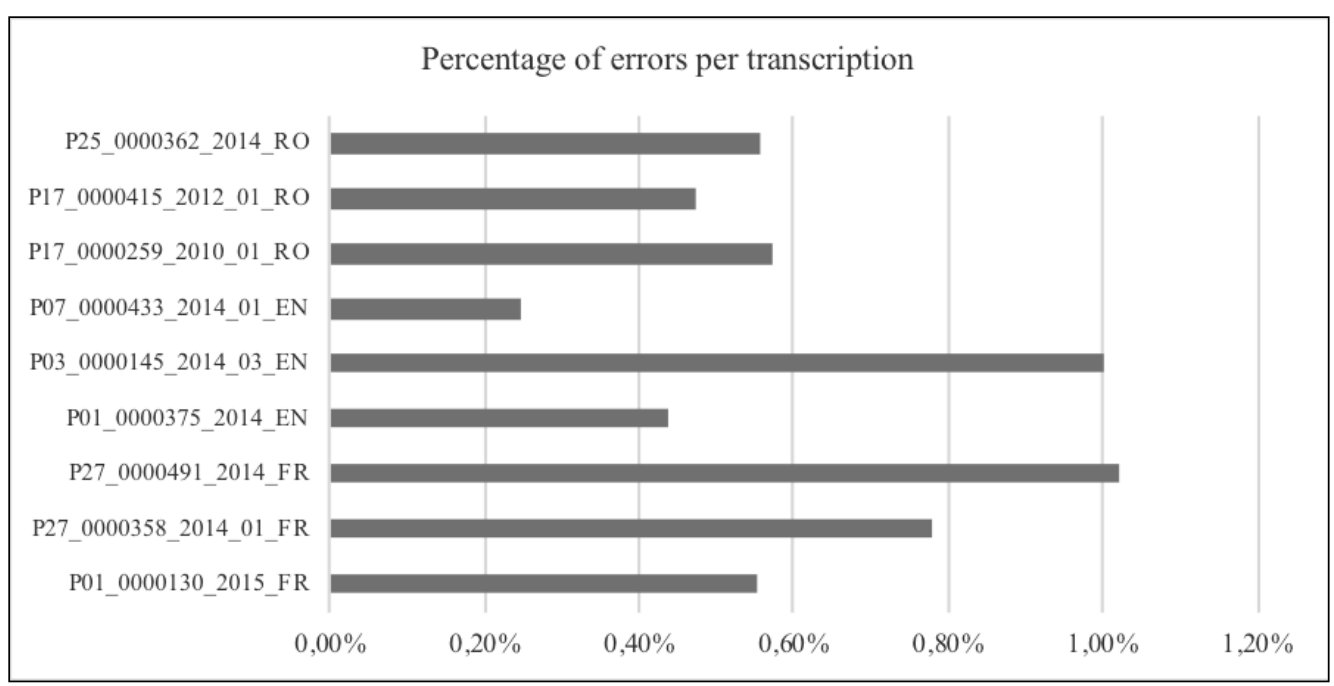

Figure 2: Percentage of errors per transcription file

Although we do not have a reference data base of a much larger corpus of transcription quality measurements to compare with, our experience leads us to consider this error rate within the range of professional grade work. It shows that the transcription work has been carried out seriously and professionally. Obviously, the error rate by itself says little about the quality of the listening effort since many errors are not material, i. e., have no impact on the understanding of the text. For that reason, our research has focused on the qualitative review of each error in order to classify them and evaluate in which circumstances these errors would lead to a different meaning of the text and therefore by extension an error-prone interpretation.

\subsection{Classification of errors}

To analyze the type of errors detected in the sample, we first discarded both the typographical errors and those related to poor audio quality in the recording as assessed by the expert (sound level too low, overlapping of different voices, poor vocalization), assuming that they were not relevant for the purpose of the present study. We classified the remaining errors into three categories described as follows. In all cases, errors were accounted when neither the transcriber nor the first reviser was able to identify and correct them.

1. Omissions: absence of recognition of the speech signal, involving principal or secondary lexical items. Omissions can be intended, i. e., the transcriber was unable to identify the word, or unintended, i. e., the transcriber simply missed the word. The convention used by transcribers to indicate an unidentified fragment in the transcription is ellipsis dots in parentheses "(...)".

2. Wrong words: wrong recognition of the lexical items

3. Incorrect phraseology: imprecise recognition of phraseological items.

In order to help formulate hypotheses explaining the root causes of these errors, we took into consideration and reflected in the tables reproduced in this section four elements: 
1. the context in which the error was detected, that is, the phase of the trial during which the intervention occurred (initial, intermediate or final phase);

2. the speaker who formulated the intervention;

3. the fragment containing the error detected; and

4. the correction carried out by the final reviser.

Although the information is available, we have not reported the transciber of each text since a first analysis showed that error statistics were very similar across the four transcribers.

\subsection{Results and analysis}

\subsubsection{Omissions}

A large number of errors detected were due to the inability to recognize some elements of the discourse, which we have classified as principal or secondary lexical items. In all our observations, we were not able to identify any unintended omissions.

Table 4: Examples of omissions involving principal lexical or phraseological items ${ }^{4}$ Omissions involving principal lexical or phraseological items

\begin{tabular}{|l|l|l|l|l|}
\hline Examples & Context & Speaker & \multicolumn{1}{|c|}{ Errors detected } & \multicolumn{1}{c|}{ Correction } \\
\hline 1 & $\begin{array}{l}\text { Initial } \\
\text { phase }\end{array}$ & Judge & $\begin{array}{l}\text { Si lo conocen o si o si desean } \\
\text { que se les lea (...) acusatorio (If } \\
\text { they are familiar with it or if or } \\
\text { if they wish to have the (...) read } \\
\text { to them) }\end{array}$ & $\begin{array}{l}\text { Si lo conocen o si o si de- } \\
\text { sean que se les lea el escrito } \\
\text { acusatorio (If they are familiar } \\
\text { with it, or if or if they wish to } \\
\text { have the prosecution pleadings } \\
\text { document read to them) }\end{array}$ \\
\hline 2 & $\begin{array}{l}\text { Inter- } \\
\text { mediate } \\
\text { phase }\end{array}$ & $\begin{array}{l}\text { Prosecu- } \\
\text { tor }\end{array}$ & $\begin{array}{l}\text { Modificaremos (...) las con- } \\
\text { clusiones provisionales (We } \\
\text { shall modify (...) the opening } \\
\text { pleadings) }\end{array}$ & $\begin{array}{l}\text { Modificaremos nuestro escrito } \\
\text { de conclusiones provisionales } \\
\text { (We shall modify our provisio- } \\
\text { nal pleadings document) }\end{array}$ \\
\hline 3 & $\begin{array}{l}\text { Inter- } \\
\text { phediate }\end{array}$ & $\begin{array}{l}\text { Prosecu- } \\
\text { tor }\end{array}$ & $\begin{array}{l}\text { Como se interesa en nuestro } \\
\text { escrito con la correspondiente } \\
\text { responsabilidad que se conside- } \\
\text { re en caso de (As is requested } \\
\text { in our plea document with the } \\
\text { corresponding liability conside- } \\
\text { red in the event of (...)) }\end{array}$ & $\begin{array}{l}\text { Como se interesaba en nuestro } \\
\text { escrito con la correspondiente } \\
\text { responsabilidad que se consi- } \\
\text { dere en caso de impago. (As } \\
\text { was requested in our pleadings } \\
\text { document with the correspond- } \\
\text { ing liability considered in the } \\
\text { event of non-payment.) }\end{array}$ \\
\hline 4 & $\begin{array}{l}\text { Initial } \\
\text { phase }\end{array}$ & $\begin{array}{l}\text { Judge } \\
\text { Lawyer }\end{array}$ & $\begin{array}{l}\text { ila letrada de la defensa? } \\
\text { (...) } \\
\text { (the defence attorney? (...)) }\end{array}$ & $\begin{array}{l}\text { ila letrada de la defensa? } \\
\text { Sí, con la venia, para interesar } \\
\text { la conformidad. } \\
\text { (the defence attorney? Yes, if } \\
\text { it please the court, to request } \\
\text { the agreement.) }\end{array}$ \\
\hline
\end{tabular}

All the examples are extracted from real cases interpreted into Spanish. The English versions here presented are not idiomatic translations but renditions for academic purposes and do not aim to serve as a standard. 


\begin{tabular}{|l|l|l|l|l|}
\hline Examples & Context & Speaker & \multicolumn{1}{|c|}{ Errors detected } & \multicolumn{1}{c|}{ Correction } \\
\hline 5 & $\begin{array}{l}\text { Final } \\
\text { phase }\end{array}$ & Judge & $\begin{array}{l}\text { ya que se acordó la prisión } \\
\text { provisional del acusado para } \\
\text { asegurar su (...) firme }\end{array}$ & $\begin{array}{l}\text { ya que se acordó la prisión } \\
\text { provisional del acusado para } \\
\text { asegurar su presencia en el } \\
\text { juicio, que se ha dictado sen- } \\
\text { tencia firme (as the accused's } \\
\text { provisional detention was ruled } \\
\text { to ensure his presence at the } \\
\text { hearing, given that a non- } \\
\text { appealable judgment has been } \\
\text { handed down) }\end{array}$ \\
\hline
\end{tabular}

In examples (1) and (2), despite the omission of the principal lexical item escrito ('document') and the phrase nuestro escrito de ('our document'), respectively, the general sense of the message is preserved. However, in examples (3), (4) and (5) the omission threatens the correct comprehension of the message.

In these cases, it is reasonable to assume that the complexity of the syntactical structure, combined with insufficient thematic knowledge, has a direct impact on the difficulty in identifying the speech signal.

To check that no other reasons caused the lack of recognition, we carried out a little "experiment". We selected another example of oral production that went unrecognized by the transcribers, and another three senior researchers from the research project listened to the fragment.

(4) Transcription:

Judge: Pues (...). ['So...]

Correction by expert:

Judge: Los otorgamientos se han realizado, [So, the offer [of actions] is made.]

They also failed to identify the linguistic signs in question, even after repetition. Since the missing words were not very technical or "uncommon" in the general language, the reason for these errors may well be rooted into the complexity of the syntax used, typical of this specialized context, involving major dislocation of the syntactical order (inversion of the subject and the verb) and the elision of a complement of the specialized noun. Therefore, thematic knowledge refers not only to semantic abstract knowledge, but also to syntactical constructions as discussed in Section 2.3.

As we shall see, the example selected shows a specific pragmatic purpose: the judge invites the parties to make whatever claim they consider appropriate, for example, regarding civil liability for the offence committed, and then goes on to state that this invitation has been made. This characteristic of legal oral language, whereby the syntactical order cannot be predicted by those not expert in legal matters, requires a greater effort of comprehension which can only be satisfactorily achieved thanks to the listener's thematic knowledge.

Another interesting point is that the error rate rises when the members of the judiciary rather than other participants are speaking. Moreover, this increase in errors occurs more often in the final phase of the oral proceedings, with the closing arguments of the parties and the judgment reading by the judges. It is reasonable to assume that the participants' tiredness and impatience to conclude might affect the quality of elocution. 


\subsubsection{Wrong words}

This consists of replacing an unidentified lexical item with other similar-sounding lexical items, regardless of whether or not the meaning coincides with the actual word. The following tables show a selection of examples of both types: with the wrong meaning or a similar meaning.

Table 5: Examples of errors involving principal lexical items

\section{Wrong words with wrong meaning}

\begin{tabular}{|c|c|c|c|}
\hline Context & Speaker & Errors detected & Correction \\
\hline $\begin{array}{l}\text { Initial } \\
\text { phase }\end{array}$ & Judge & $\begin{array}{l}\text { Procedemos a la celebración de la vista } \\
\text { correspondiente al procedimiento abrevi- } \\
\text { ado número } 208 / 2012 \text { en el que exige la } \\
\text { acusación del Ministerio } \\
\text { (We move on to the hearing corresponding } \\
\text { to abbreviated proceeding No. 208/2012 in } \\
\text { which the Public Prosecutor demands) }\end{array}$ & $\begin{array}{l}\text { Procedemos a la celebración de } \\
\text { la vista correspondiente al pro- } \\
\text { cedimiento abreviado número } \\
208 / 2012 \text { en el que ejerce la } \\
\text { acusación el Ministerio (We } \\
\text { move on to the hearing corres- } \\
\text { ponding to abbreviated proceed- } \\
\text { ing No. } 208 / 2012 \text { in which the } \\
\text { prosecution is brought by the } \\
\text { Public Prosecutor) }\end{array}$ \\
\hline Final phase & Prosecutor & $\begin{array}{l}\text { Y aproximación a la víctima cualquiera } \\
\text { que sea el lugar (...) que se encuentre, que } \\
\text { en este caso es la señora Mariana F. por } \\
\text { el tipo de los años (And approaching } \\
\text { the victim, in this case Mrs Mariana F., in } \\
\text { whatever place she may be for the type of } \\
\text { the years) }\end{array}$ & $\begin{array}{l}\text { Y aproximación a la víctima } \\
\text { cualquiera que sea el lugar en } \\
\text { que se encuentre, que en este } \\
\text { caso es la señora Mariana F. } \\
\text { por el tiempo de dos años } \\
\text { (And approaching the victim, } \\
\text { in this case Mrs Mariana F., in } \\
\text { whatever place she may be for a } \\
\text { period of time of two years) }\end{array}$ \\
\hline Final phase & Prosecutor & los costos procesales (the fees) & $\begin{array}{l}\text { las costas procesales (the costs } \\
\text { of proceedings) }\end{array}$ \\
\hline $\begin{array}{l}\text { Initial } \\
\text { phase }\end{array}$ & Judge & $\begin{array}{l}\text { Se ha leído el acto de manifestación (The } \\
\text { statement act has been read) }\end{array}$ & $\begin{array}{l}\text { Se ha leído el acta de manifesta- } \\
\text { ción (The statement record has } \\
\text { been read) }\end{array}$ \\
\hline $\begin{array}{l}\text { Intermedi- } \\
\text { ate phase }\end{array}$ & Prosecutor & $\begin{array}{l}\text { Por el agente de ponente (By the re- } \\
\text { porting officer) }\end{array}$ & $\begin{array}{l}\text { Por el agente deponente (By } \\
\text { the officer who took the state- } \\
\text { ment) }\end{array}$ \\
\hline $\begin{array}{l}\text { Initial } \\
\text { phase }\end{array}$ & Judge & $\begin{array}{l}\text { Se da inicio al acta de la vista (The hearing } \\
\text { record commences) }\end{array}$ & $\begin{array}{l}\text { Se da inicio al acto de la vista } \\
\text { (The hearing proceedings } \\
\text { commence) }\end{array}$ \\
\hline Final phase & $\begin{array}{l}\text { Defence } \\
\text { lawyer }\end{array}$ & $\begin{array}{l}\text { Si su señoría parecía que se ha cometido } \\
\text { algún hecho (If your honour seemed that } \\
\text { some act has been committed) }\end{array}$ & $\begin{array}{l}\text { Si su señoría aprecia que se ha } \\
\text { cometido algún hecho (If your } \\
\text { honour deems that some act has } \\
\text { been committed) }\end{array}$ \\
\hline Final phase & $\begin{array}{l}\text { Defence } \\
\text { lawyer }\end{array}$ & $\begin{array}{l}\text { No se ha aportado pericial (No testimony } \\
\text { has been put forward) }\end{array}$ & $\begin{array}{l}\text { No se ha practicado pericial } \\
\text { (No expert testimony has been } \\
\text { drafted) }\end{array}$ \\
\hline
\end{tabular}


Table 6: Examples of errors involving principal lexical items, but with the overall sense preserved

Wrong words, but with the overall sense preserved

\begin{tabular}{|c|c|c|c|}
\hline Context & Interlocutor & Errors detected & Correction \\
\hline Initial phase & Defence lawyer & $\begin{array}{l}\text { No, no he sido asignado de } \\
\text { oficio (No, I have not been } \\
\text { assigned de officio) }\end{array}$ & $\begin{array}{l}\text { No, no he sido designado de } \\
\text { oficio (No, I have not been } \\
\text { designated de officio) }\end{array}$ \\
\hline Initial phase & Judge & $\begin{array}{l}\text { Pues ya pueden regresarlo (So, } \\
\text { you can return him) }\end{array}$ & $\begin{array}{l}\text { Pues ya pueden reingresarlo } \\
\text { (So, you can take him back to } \\
\text { prison) }\end{array}$ \\
\hline $\begin{array}{l}\text { Intermediate } \\
\text { phase }\end{array}$ & Defence lawyer & $\begin{array}{l}\text { por entender que los hechos } \\
\text { enjuiciados no se pueden } \\
\text { encuadrar dentro del artículo } \\
368 \text { del vigente Código Penal } \\
\text { (since in our opinion the facts } \\
\text { tried cannot be framed within } \\
\text { Article } 368 \text { of the current Cri- } \\
\text { minal Code) }\end{array}$ & $\begin{array}{l}\text { por entender que los hechos } \\
\text { enjuiciados no se pueden incar- } \\
\text { dinar dentro del artículo } 368 \\
\text { del vigente Código Penal (since } \\
\text { in our opinion the facts tried } \\
\text { cannot be enshrined in Article } \\
368 \text { of the current Criminal } \\
\text { Code) }\end{array}$ \\
\hline Final phase & Prosecutor & $\begin{array}{l}\text { Para desligar el delito de la falta } \\
\text { (In order to separate the crime } \\
\text { from the minor offence }\end{array}$ & $\begin{array}{l}\text { Para deslindar el delito de la } \\
\text { falta (In order to differenti- } \\
\text { ate the crime and the minor } \\
\text { offence) }\end{array}$ \\
\hline Initial phase & Defence lawyer & $\begin{array}{l}\text { Es que han enjuiciado a quien } \\
\text { no era (They have tried the } \\
\text { wrong person) }\end{array}$ & $\begin{array}{l}\text { Es que han escuchado a quien } \\
\text { no era (They have heard the } \\
\text { wrong person) }\end{array}$ \\
\hline $\begin{array}{l}\text { Intermediate } \\
\text { phase }\end{array}$ & Defence lawyer & $\begin{array}{l}\text { Al folio } 362 \text { de las acusaciones } \\
\text { (To page } 362 \text { of the accusa- } \\
\text { tions) }\end{array}$ & $\begin{array}{l}\text { Al folio } 362 \text { de las actuaciones } \\
\text { (To page } 362 \text { of the proceed- } \\
\text { ings) }\end{array}$ \\
\hline
\end{tabular}

In the aforegoing examples we find a lexical substitution. Most of the time the substitution displayed similarities in pronunciation. But the semantic differences did not trigger the appropriate warning to prevent the transcriber from proceeding with her proposed term, which means that neither the transcriber nor the reviewer had the thematic expertise to detect the semantic difference.

It should also be pointed out that Spanish spelling tends to be phonemic and that the examples shown are not attributable to spelling difficulties or any particular complexity, but rather to a simple lack of recognition.

\subsubsection{Incorrect phraseology}

Most of the phraseology errors were related to minor alterations or modifications being made involving the lesser parts of speech such as articles and prepositions, or incorrect written punctuation of the pauses. However, it often resulted in incomprehensible phrases as shown in the examples in the following table. 
Table 7: Example of phraseology errors

Phraseology errors

\begin{tabular}{|c|c|c|c|}
\hline Context & Interlocutor & Errors detected & Correction \\
\hline Final phase & $\begin{array}{l}\text { Defence } \\
\text { lawyer }\end{array}$ & $\begin{array}{l}\text { A definitiva, si formulamos alter- } \\
\text { nativas igual que el resto de mis } \\
\text { compañeras, señoría. En el segundo } \\
\text { punto de las conclusions (Submit- } \\
\text { ted as final, if we propose alterna- } \\
\text { tives, like my other colleagues, Your } \\
\text { Honour, In the second point of the } \\
\text { pleadings) }\end{array}$ & $\begin{array}{l}\text { A definitivas y formulamos alter- } \\
\text { nativas igual que el resto de mis } \\
\text { compañeras, señoría, en el segundo } \\
\text { punto de las conclusions (Submit- } \\
\text { ted as final, and we propose alter- } \\
\text { natives, like our other colleagues, } \\
\text { Your Honour. In the second point of } \\
\text { the pleadings) }\end{array}$ \\
\hline $\begin{array}{l}\text { Intermedi- } \\
\text { ate phase }\end{array}$ & Prosecutor & $\begin{array}{l}\text { Estas conclusions se elevarían a la } \\
\text { definitivas las conclusions una } \\
\text { acta de defensa que manifieste en } \\
\text { su conformidad, también la acu- } \\
\text { sación particular y el acusado a } \\
\text { manifestar en su conformidad con } \\
\text { los hechos y con (...) la intención } \\
\text { por parte del Ministerio Público } \\
\text { (These pleadings would be submit- } \\
\text { ted as the final conclusions an act } \\
\text { of defence that expresses in its } \\
\text { agreement, and also the private } \\
\text { prosecution and the defendant } \\
\text { expresses his acceptance of the } \\
\text { facts and with (...) the intention } \\
\text { on the part of the Public Prose- } \\
\text { cutor) }\end{array}$ & $\begin{array}{l}\text { Estas conclusions se elevarían a } \\
\text { definitivas una vez que la defensa } \\
\text { manifieste su conformidad. Tam- } \\
\text { bién la acusación particular y el } \\
\text { acusado. Manifestar su conformi- } \\
\text { dad con los hechos y con las pen- } \\
\text { as que se interesan por parte del } \\
\text { Ministerio Público (These plead- } \\
\text { ings would be submitted as final, } \\
\text { once the defence has expressed its } \\
\text { agreement. Likewise the private } \\
\text { prosecution and the defendant. } \\
\text { Once they have expressed their } \\
\text { acceptance of the facts and the } \\
\text { sentence asked for by the Public } \\
\text { Prosecutor) }\end{array}$ \\
\hline
\end{tabular}

This apparent paradox of mistakes made involving lesser parts of the text while having some serious impact on the meaning is a clear sign of a lack of expression recognition capability by the transcriber. Only thematic knowledge and practice can shape such a capability and trigger accurate recognition.

\subsection{Comments on the results}

The results presented in this paper show that the transcribers were quite concentrated on their task - otherwise many general errors would also appear - but a good focus on their task was not sufficient to prevent legal context-driven errors that they failed to spot even after a further revision.

We observe also that training in the theoretical foundations of criminal law and procedural law does not adequately equip them to recognize the sounds heard in a criminal trial. Greater exposure to oral legal discourse in real contexts is therefore necessary to improve comprehension skills.

In our opinion, the transcription task carried out in this research shows that comprehension is a continuous, circular process in which the recognition of the speech signal tends to be incomplete if the listener does not possess sufficient lexical resources appropriate to the context in which the interaction occurs to construct a coherent representation of what is heard. Anticipating this factor, we included many specialized terms and formulaic expressions in the 
training seminars, but we clearly failed to realize the impact of thematic knowledge on the recognition of fairly "non-complex" words.

To summarize the analysis of the data obtained, we observe that the transcription of judicial texts is not an error-free process, despite the fact that the transcribers were at liberty to replay the recordings as many times as they wished. We also observe that the nature of the errors is to a large extent linked to the misunderstanding of words used in legal expressions. These words (escrito, nuestro escrito de, interesaba, impago, etc.) in isolation may not pose any listening challenge since, as shown in the work, they are not complex words such as might be encountered in a very technical field, but their combination with other words to create a specific legal meaning was lost on the transcriber and therefore did not trigger the appropriate listening response. Moreover, it is important to note that Spanish is a highly phonetic language and the errors detected are not the consequence of a spelling difficulty.

We also note that transcription errors are more numerous when dialogue exchanges occur between the members of the communicative triangle formed by judges, prosecutors and attorneys, where the complexity of the syntactical formulations and the density of uncontextualized terminology require a greater effort of comprehension on the part of the transcribers. Quite often in these phases there is a combination of formulaic legal expressions which are enunciated with careless elocution. All indications are that in oral trial proceedings, greater attention is focused on extracting information from the defendant than on providing him or her with information and this has an impact on vocalisation.

These observations suggest that expert knowledge really is necessary to ensure full recognition of the speech signal and, therefore, to achieve complete comprehension of the oral discourse of a complex field of expertise. Complexity is usually understood as the usage of highly technical words that are definitely not part of a mainstream culture. To use a medical analogy, one could anticipate that words such as neuroblastoma or epinephrine in a medical conversation/speech would pose a challenge to the listening effort of a non-expert listener, while the latter would likely have no difficulty in recognising terms such as $l e g$, arm, etc.

Contrary to the above-mentioned example, the findings in this work show almost the opposite: trained transcribers were able to recognize technical words, their legal knowledge helped them to predict the right words, but failed to recognize some complex syntactical formulations consisting only of "common" words, thus incurring serious deviations from the original meaning.

According to our assumption that we can extrapolate the issues facing transcribers in the listening phase with those confronting the interpreter, the results of the analysis of the transcription difficulties may be indicative of similar problems in court interpreting, since the recordings are not a simulated environment. They suggest that a higher degree of expertise is required for interpreters and translators wishing to work in court interpreting. Expertise means not only some knowledge of the legal terms and phraseology, but also depends on high exposure to legal discourse in real contexts. Fluency is required in the legal words and expressions that are used and their contextual meaning. Such expertise goes beyond both the knowledge of the legal framework of the legal institutions and the reading of legal texts to build some familiarity with the legal vocabulary. It requires practice and the use of teaching materials created on the basis of the oral language actually used in the Spanish courts. In our opinion, the results of our analysis may be an indicator of the challenges facing legal interpreters and are a good starting point to increase awareness on the linguistic and extralinguistic anticipation skills that court interpreters need to acquire. 
The results presented here may at first sight seem commonplace, but since the transcribers were all intensively trained in the relevant field of expertise, the errors detected emphasized the need to increase their training in recognition of the speech in the source language. Theoretical contents, including doctrine, judgments and other legal texts, are not sufficient to provide the level of knowledge required in this special oral setting, where the words used ( $a$ definitivas, por reproducidas, etc.) do not figure in the legal texts oriented to interpreters and, moreover, they are embodied in complex syntactical utterances. Our transcribers were trained in the criminal and procedural legal system of Spain, but their contact with the context of communication was proven insufficient to ensure their full comprehension of the speech they had to transcribe. In the subsequent phases of the transcribing process, after the pilot period, we intensified training using actual recordings and revisions of the errors detected, as a result of which the outputs gained in quality, but expert revision was always necessary.

\section{Conclusion}

The very considerable difficulties experienced by the transcribers in recognizing certain formulations which posed no problem for the reviser, by whom they were correctly identified, and which had a serious impact on the meaning of the text, allowed us to analyze the relative importance of expert knowledge and to show that there is a greater or lesser frequency of transcription errors, depending on the dialogic situation. An analysis of the transcription errors detected gives us an idea of the types of problems of speech recognition and, in particular, the impact of the complexity of legal discourse on the comprehension errors detected. Although the objective of transcribing the oral trials in this research project is not to investigate the interpreters' listening ability, but rather to describe interpretation as it is practised in the criminal courts of Barcelona, given the procedure followed, the data obtained have allowed us to make a brief foray into the field of the court interpreter's listening effort. The analysis carried out in this study regarding the correlation between thematic knowledge and comprehension problems in the context of oral communication in criminal proceedings in Spain suggests that the listening effort that is required of interpreters is higher when the person delivering the speech is a member of the judiciary and that this effort has to be intensified in the final phases of the trial, not only due to the intensity of information, but also to the complexity of syntax and careless articulation. Therefore, although we cannot directly quantify or extrapolate these findings to the task of the court interpreter, the analysis of the transcription errors does enable us to contribute to raise the awareness of the judiciary concerning the task that court interpreters are required to perform.

We propose that greater exposure to oral legal discourse in real contexts is necessary to improve comprehension skills in interpreter training, as was applied in the following phases of the transcription work with our transcribers.

However, we concur with Ozolins and Hale (2009) that the quality of the interpretation provided is a responsibility that must be shared by all legal professionals. This state of affairs, which clearly needs to be improved if the social group to whom legal oratory is addressed is also intended to include defendants, is one in which the interpreter finds him/herself bearing sole responsibility for the enormous effort of communicating and relaying information to the user of the interpretation - defendant, victim or witness - who is unacquainted with the language in which the trial is being conducted. While an improvement in interpreter-mediated verbal communication must always be a goal, when the end-user of the interpreting service is 
the defendant, failure to provide the interpreter with the conditions necessary to ensure effective communication entails not only a problem of quality in the interpretation, but also a clear example of the breach of the right to legal defence. The present study opens up a new line of research into court interpreting in Spain: namely, the comprehension of specialized language. Future research might profitably replicate the study with the participation of expert interpreters as well as trained interpreters who are not specialized in court interpreting.

\section{Acknowledgments}

The author is very grateful to the anonymous reviewers of this paper for their careful and meticulous reading on an earlier version of this work and to the translator. The translation of this article has been supported by the Department of Translation and Interpreting and East Asian Studies.

\section{References}

Alcaraz, Enrique/Hughes, Brian (2002): Legal Translation Explained. Manchester: St. Jerome.

Angelelli, Claudia (2004): Revisiting the Interpreter's Role: A Study of Conference, Court, and Medical Interpreters in Canada, Mexico and the United States. Amsterdam/Philadelphia: Benjamins.

Angermeyer, Philip S. (2009): "Translation Style and Participant Roles in Court Interpreting." Journal of Sociolinguistics 13.1: 3-28.

Bajo, Maria Teresa/Padilla, Francisca/Padilla, Presentación (2000):“Comprehension Processes in Simultaneous Interpreting." Translation in Context. Eds. Andrew Chesterman, Natividad Gallardo San Salvador and Yves Gambier. Amsterdam/Philadelphia: Benjamins. 127-142.

Berk-Seligson, Susan (1990/2002): The Bilingual Courtroom. Court Interpreters in the Judicial Process. Chicago: The University of Chicago Press.

Bestué, Carmen (2013): Los contratos traducidos. La traducción de los contratos de licencia de uso de programas de ordenador. Colección Derecho y TICs. Valencia: Tirant lo Blanch.

Bestué, Carmen (2016): "Translating Law in the Digital Age. Translation Problems or Matters of Legal Interpretation?" Perspectives: Studies in Translatology 24.4: 576-590. 05.12.2017 <http://www.tandfonline.com/ doi/full/10.1080/0907676X.2015.1070884>.

Borja, Anabel/García-Izquierdo, Isabel (2016): "Web-based Tools and Resources for Legal Translators: the JudGENTT Translation-Oriented Glossaries for Criminal Courts Translators." Onomázein 33: 226-250.

Bucholtz, Mary (2009): "Captured on Tape: Professional Hearing and Competing Entextualizations in the Criminal Justice System." Text \& Talk 29.5: 502-523.

Calvo, Elisa (2002): "La influencia de la asimetría procesal en la traducción jurídica: procedimientos de separación y divorcio en Irlanda y España." Puentes 2: 37-52.

Chiari, Isabella (2007): "Transcribing Speech: Errors in Corpora and Experimental Settings." Proceedings of the Corpus Linguistics Conference (CL2007). Eds. Matthew Davies, Paul Rayson, Susan Hunston et al. Birmingham: University of Birmingham. 1-13.

Colin, Joan/Morris, Ruth (1996): Interpreters and the Legal Process. Winchester: Waterside Press.

Dillinger, Mike (1994): “Comprehension during Interpreting: What do Interpreters Know that Bilinguals don't?" Bridging the Gap: Empirical Research in Simultaneous Interpretation. Eds. Sylvie Lambert and Barbara Moser-Mercer. Amsterdam: Benjamins. 155-189.

Dueñas, Roseann/Vásquez, Victoria F./Mikkelson, Holly (2012): Fundamentals of Court Interpretation: Theory, Policy, and Practice. 2nd ed. Durham, NC: Carolina Academic Press. 
Escudero Domínguez, Inmaculada (2010): “Las inferencias en la comprensión lectora: Una ventana hacia los procesos cognitivos en segundas lenguas." Revista Nebrija de Lingüística Aplicada 7.

Fishman, Clifford (2006): "How to Translate a Recording, Testify about it, and Survive the Experience." ATA Cronicle 35.8: 22-26.

Fraser, Helen (2003): "Issues in Transcription: Factors Affecting the Reliability of Transcripts as Evidence in Legal Cases." Forensic Linguistics 10.2: 203-226.

Gile, Daniel (1989) : « Les flux d'information dans les réunions interlinguistiques et l'interprétation de conférence : premières observations. » Meta 34.4: 649-660.

Gile, Daniel (2009a): Basic Concepts and Models for Interpreter and Translator Training. Revised edition. Amsterdam/Philadelphhia: Benjamins.

Gile, Daniel (2009b): "Interpreting Studies: A Critical View from within." MonTI. Monografías de Traducción e Interpretación 1: 135-155.

Griffin, Patricia W./Cole, Stephanie J. (2007): "White Paper on Court Interpretation: Fundamental to Access to Justice." Policy Papers of the Conference of State Court Administrators. 05.12.2017 <http://cosca.ncsc. org/ /media/Microsites/Files/COSCA/Policy\%20Papers/CourtInterpretation-FundamentalToAccessToJustice.ash $x>$.

Hale, Sandra (2004): The Discourse of Court Interpreting. Discourse Practices of the Law, the Witness and the Interpreter. Amsterdam/Philadelphia: Benjamins.

Hale, Sandra (2007): "The Challenges of Court Interpreting. Intricacies, Responsibilities and Ramifications." Alternative Law Journal 32: 198-202.

Hunt-Gómez, Coral Ivy (2015): La aplicación de las nuevas tecnologías a la formación de intérpretes en los tribunals de justicia mediante la utilización de material real. Doctoral thesis. Universidad de Granada.

Lambertini, Julia (2016): Comprehension of Legal Discourse in Interpreter-Mediated Judicial Proceedings. Doctoral thesis. Universitat Rovira i Virgili Tarragona.

León, José Antonio (2001): “Las inferencias en la comprensión e interpretación del discurso: Un análisis para su estudio e investigación." Revista Signos 34.49-50: 113-125.

Martin, Anne/Ortega, Juan Miguel (2013): "From Invisible Machines to Visible Experts. View on Interpreter Role and Performance during the Madrid Train Bomb Trials." Interpreting in a Changing Landscape. The Critical Link 6, Birmingham, 26-30 July 2010. Vol. 109. Eds. Christina Schäffner, Krzysztof Kredens and Yvonne Fowler. Amsterdam/Philadelphia: Benjamins. 101-114.

Mayoral, Roberto (2003): Translating Official Documents. Manchester: St. Jerome.

Meyer, Bernd (1998): "What Transcriptions of Authentic Discourse Can Reveal about Interpreting." Interpreting 3.1: $65-83$.

Mikkelson, Holly (2010): "Consecutive or Simultaneous? An Analysis of their Use in the Judicial Setting." Across the Board, Australian Sign Language Interpreters' Association 5.1: 4-7.

Montolío, Estrella, ed. (2012): Hacia la modernización del discurso jurídico. Barcelona: Universitat de Barcelona. Niemants, Natacha S. A. (2012): "The Transcription of Interpreting Data." Interpreting 14.2: 165-191.

Onos, Liudmila (2014): La interpretación en el ámbito judicial: el caso del rumano en los tribunales de Barcelona. Doctoral thesis. Universitat Autònoma de Barcelona.

Orozco-Jutorán, Mariana (2018): "The TIPp Project: Developing Technological Resources Based on the Exploitation of Oral Corpora to Improve Court Interpreting." InTRAlinea 20. 26.11.2018 <http://www.intralinea. org/specials/article/the_tipp_project>.

Ortega, Juan Miguel (2015): "Reflexiones en torno al binomio formación-acreditación como elementos constitutivos de la profesionalización de la interpretación jurídica." Trans 19.1: 131-152.

Orts, María Ángeles (2015): "Opacity in International Legal Texts: Generic Trait or Symbol of Power?" Revista Alicantina de Estudios Ingleses/Alicante Journal of English Studies 28: 119-145. 
Orts, María Ángeles/Almela, Ángela (2014): "Corruption in Words: A Study of Spanish and English Criminal Terminology in Europe." LSP Journal 5.1: 21-40.

Ozolins, Uldis/Hale, Sandra (2009): "Introduction. Quality in Interpreting: A Shared Responsibility." Quality in interpreting - a shared responsibility. The Critical Link 5, Sydney, 11-15 April 2007. Eds. Sandra Hale/Uldis Ozolins, Ludmila Stern. Amsterdam/Philadelphia: Benjamins. 1-10.

Padilla, Francisca/Bajo, María Teresa/Macizo, Pedro (2005): “Articulatory Suppression in Language Interpretation: WM Capacity, Dual Tasking and Word Knowledge." Bilingualism: Language and Cognition 8.3: 207-219.

Pallaud, Berthille (2002) : «Erreurs d'écoute dans la transcription de données orales. » Revue parole 22-24: 267-294.

Peñaranda, Antonio (2011): El proceso penal en España, Francia, Inglaterra y Estados Unidos: descripción y terminología. Granada: Comares.

Pfeiffer, J. William (1998): “Conditions that Hinder Effective Communication. The Pfeiffer Library. Vol. 6. 2 ${ }^{\text {nd }}$ ed. Ciudad: Jossey-Bass/Pfeiffer: 1-5.

Philipsen, Gerry (1992): Speaking Culturally: Explorations in Social Communication. New York: State University of New York Press.

Prieto-Ramos, Fernando (2015): "Quality Assurance in Legal Translation: Evaluating Process, Competence and Product in the Pursuit of Adequacy." International Journal for the Semiotics of Law 28.1:11-30.

Pym, Anthony (1999): "'Nicole Slapped Michelle' - Interpreters and Theories of Interpreting at the O.J. Simpson Trial." The Translator 5.2: 265-283.

Rainof, Álex (2011): "The Lessons of the Méndez Case: Suggested Transcription, Translation and Interpretation Assessment Methodology for the Courts." Proteus XX.4: 1-8.

Roberts-Smith, Len (2009): "Forensic Interpreting. Trial and error." Quality in interpreting - a shared responsibility. The Critical Link 5, Sydney, 11-15 April 2007. Eds. Sandra Hale, Uldis Ozolins, Ludmila Stern. Amsterdam/Philadelphia: Benjamins. 13-35.

Ruiz, María Ángeles (2013): “Cognition and Context of Legal Texts: Spanish and English Judgments Compared." Revista de Lingüística y Lenguas Aplicadas 8: 76-92.

Sánchez-Ramos, María del Mar/Vigier-Moreno, Francisco Javier (2016): “Using Corpus Management Tools in Public Service Translator Training: An Example of its Application in the Translation of Judgments." New Perspectives on Teaching and Working with Languages in the Digital Era. Eds. Antonio Pareja-Lora, Cristina Calle-Martínez, and Pilar Rodríguez-Arancón. Dublin: Research-publishing.net: 375-384.

Soler Caamaño, Emma (2006): La calidad en formación especializada en interpretación: Análisis de los criterios de evaluación de un jurado en un posgrado de interpretación de conferencia médica. Barcelona: Universitat Pompeu Fabra.

Soriano, Inmaculada (2004): La traducción de expedientes de crisis matrimoniales entre España e Irlanda: Un estudio jurídico-traductológico. Granada: Universidad de Granada.

Tolosa, Miguel (2014): “Estratos de comprensión y conciencia de error en la traducción de textos especializados." XII Jornades de Xarxes d'investigació en docència universitària. El reconeixement docent: innovar i investigar amb criteris de qualitat. Coords. María Teresa Tortosa Ybáñez, José Daniel Álvarez Teruel, Neus Pellín Buades. Alicante: Universidad de Alicante. 1267-1285.

Torres Álvarez, José (2016): La argumentación en discursos jurídicos: análisis pragmagramatical. Doctoral thesis. Universidad Complutense de Madrid 31.07.2018 <https://eprints.ucm.es/40131/1/T38022.pdf>.

Trabing, Eta (2002): Introduction to Court Interpreting. Houston: Berkane Language Center. Wadensjö, Cecilia (1998): Interpereting as interaction. London/New York: Longman. 
Carmen Bestué

Department of Translation and Interpreting \& East Asian Studies Autonomous University of Barcelona

Pl. del Coneixement-Edifici K-Campus de la UAB 08193 Bellaterra (Cerdanyola del Vallès) - Barcelona (Spain)

Tel. +34935813376

carmen.bestue@uab.cat 